\title{
Faith-Based Organizations and Social Development: The Role of *Markazosshabab Al-Muslim Fil Filibbin in Women Empowerment
}

\author{
El Fatih Abdullahi Abdelsalam, Nadhera Mohammad Qassem \\ International Islamic University Malaysia, Kuala Lumpur, Malaysia
}

\begin{abstract}
Recently, the issue of women empowerment has gained scholarly interest. This is not only confined to theoretical debate but it has morphed into practical exercise whereby women nowadays have become more empowered and have been assuming an active role in society. However, little is known about the role of faith on women empowerment in this intellectual pursuit. This study takes a leap to investigate if there is a role of faith in empowering women. It tries to examine if faith itself can be a determining factor to embolden women involvement in the society. Being embedded in Islamic principles and values, a faith-based organization in the Philippines called Markazosshabab al-Muslim fil Filibbin is taken as a case study particularly its women department. It examines the role of women in multidimensional aspects. It attempts to explore if women involved in this faith-based organization have become empowered due to the religious principles and values this group is built upon. The study found that women's lives have been transformed in society. They have become more active in playing their multifaceted role to their family, society, and politics.
\end{abstract}

Keywords: faith-based organization, social development, women empowerment, Islam, Philippines

Transformation of a society from tradition to modernity is what characterizes contemporary times. This is what takes place in the modernization process whereby change is a determinant factor. To modernize society is to develop multi-dimensional aspects. Those are economic, political, cultural, and social aspects. Hence, the concept of development is often associated with modernization as what Schmidt has specified in his theory of modernization is its emphasis on the economic and political subsystems including the educational system, the scientific system, the legal system, and the system of mass media (Schmidt, 2010).

In the language of modernization, faith does not have a role in development. It is bygone past that is no longer relevant in modernization exercise. In fact, faith is believed to be an anti-thesis to modernity. This has procured in the period of industrial revolution period in Europe wherein the power of church had left Europe in

\footnotetext{
${ }^{*}$ Markazosshabab al-Muslim fil Filibbin is the name of this Islamic organization being studied. It is an Arabic terminology which means Youth Center of the Philippines.

El Fatih Abdullahi Abdelsalam, Ph.D. in Political Science from Northwestern University, USA, a professor in Department of Political Science, International Islamic University Malaysia, Kuala Lumpur, Malaysia; research fields: contemporary Islamic political thought and movements, international political economy, conflict and conflict resolution, and Middle Eastern politics.

Corresponding author: Nadhera Mohammad Qassem, a doctoral candidate of Political Science in Department of Political Science, International Islamic University Malaysia, Kuala Lumpur, Malaysia; research fields: international relations, political Islam, social development, peace studies, and comparative politics.
} 
backwardness. From that point, religion is viewed as incapable of bringing society to advancement. This view has proliferated in both theory and practice on modernization or development literature. It is only later on that the role of religion has attracted researchers and scholars by examining its role of faith in development.

Be that as it may, this examines the role of faith in development, specifically social development. This notion of development covers empowerment of women which is the focus of this study. It examines the role of faith in empowering women by taking one faith-based organization in the southern Philippines called Markazosshabab al-Muslim fil Filibbin as a case study. It is an organization that is built upon Islamic principles, values, and ideals. Interviews, magazines, journals, theses, and reports are used as sources of data where thematic analysis is employed.

\section{Definition of Terms}

Some terms are to be operationally defined as these have been used in this study. Firstly, faith-based organizations and religious organizations are used interchangeably by scholars. The former term rose with the emergence of the Religious Right in the United States (Rakodi, 2013). It became more prominent after the Bush administration created the Office of Faith-Based Activities (Lee Mardsen, 2008). This study treats both faith-based organizations and religious organizations as depicting the same terms. However, due to its wider usage by scholars, this research opts to use the term: faith-based organizations throughout this study. Smith and Sosin considered an organization as religious or "faith-related" if it has a formal, administrative, or historical arrangement with a religious authority, or a specific mission that arises out of explicit religious values (Chaves, Stephens, \& Galaskiewicz, 2014; Vanderwoerd, 2008). This study defines faith-based organization as an entity, independent of the government, which works towards improving the welfare and social development of particular communities.

Secondly, social development, as a distinctive concept, stems from the wider and more generic concept of development. Development, conventionally, is always associated with social change by which a society moves from culturally-bound society into modernity by adopting the western way of modernization. With the evolutionary definition and variance of the term comes the concept of social development. It is another concept that falls under wide array of development processes. Sen (1995) defined social development as equality of social opportunities to which people are the point of concentration. It touches the area of community life, participation, non-discrimination, social empowerment, and trust (Foa, 2014). Social development approach focuses on issues such as poverty, literacy, youth, women empowerment, and skills training for rural dwellers because development is measured under this perspective in terms of how marginalized groups are taken care of. Hence,

Poverty reduction, for example, is a requisite upon giving individuals the knowledge, skills, and human capital that enables investment and growth, but building human capital in an equitable fashion which in turn requires institutions that are inclusive of women and minorities that foster trust and cooperation, and deliver accountability in governance. (Foa, 2014, p. 4)

This study takes women empowerment under the propositional definition of what social development should be. Social development treats people as the target of development which includes women by empowering them.

\section{Formation of Markazosshabab Al-Muslim Fil Filibbin}

Markazosshabab al-Muslim fil Filibbin or Center for Muslim youths in the Philippines is a non-governmental organization based mainly in Lanao del Sur. It was informally founded in 1978. However, 
the formal recognition of the Philippine government took effect when it was registered in Security Exchange in 1981. The very foundation of Markazossoshabab took place in Kuwait by a group of students led by the late Mohammad Qassem who initiated a grand plan of forming that Islamic organization. The founder perceived the need of founding an Islamic organization that would be based on Islamic $d a$ 'wah which would be a catalyst to reform the society ${ }^{1}$. The inspiration of founding the organization was the presence of organizations in other parts of the world especially in the Middle East built with systematic structures and patterns. This had been the blueprint followed by these groups of Muslim students in Kuwait to organize their own group back in Kuwait and consequently brought it to the Philippines.

\section{Women Empowerment}

Empowerment means increasing the spiritual, political, social, educational, gender, or economic strength of individuals and communities to deliver an authority or permission. Empowering women is seen as means to achieving development. The role of women in society cannot go unnoticed because it is crucial for achieving development goals. Hence, empowering them is necessary as they are partners of men achieving common goals of reforming the society. Malhotra and Schuler (2004) posited that the promotion of women's empowerment as a development goal is based on dual argument: Social justice is an important aspect of human welfare and is intrinsically worth pursuing; and women's empowerment is a means to the other ends.

Islam never excludes the affair of women in its development programs. The status of women in Islam is, in fact, precious because they are the builder of the nation. In their womb starts the very initial stage of society. They are the maker of leaders of society. Hence, Allah has given inherent right over them regarding their status and they should be treated as they should be treated accordingly. The status of women was downgraded in time of ignorance (jahiliyyah) or before Muhammad received revelation. Historically, there were groups of Arab tribes who were in shame of giving birth to women until they mercilessly buried their daughters alive for having daughter offsprings. But the advent of Islam eradicated this barbaric act and bestowed on women with higher status. This is readily comprehensible in the teaching of Islam through prophetic tradition:

A man came to the Prophet and said, "O Messenger of God! Who among the people is the most worthy of my good companionship?" The Prophet said: Your mother. The man said, "Then who?” The Prophet said: Then your mother. The man further asked, "Then who?" The Prophet said: Then your mother. The man asked again, "Then who?" The Prophet said: Then your father. (Asim \& Bukhari, 2013)

Not only through prophetic traditions the status of women in Islam is exalted but it has one separate chapter in the whole book of Quran that is titled "Women". The fact that Islam expects men to provide for and take care of women is very telling in the verse: "Men are the protectors and maintainers of women, because Allah has made one of them to excel the other, and because they spend (to support them) from their means"2. Men are expected to protect and maintain women as this verse suggests.

Empowerment, as Floyd puts it, is increasing the political, social, educational, gender, or economic strength of individuals and communities to deliver an authority or permission (cited in Asim \& Bukhari, 2013). Women empowerment in Islam is that Muslim women have a share in society and enjoy the opportunity to partake in the development of society. Their pivotal role is religiously motivated in promoting the welfare of

\footnotetext{
${ }^{1}$ Personal communication, Bo. Green, Marawi City, December 28, 2014.

2 Quran, Chapter 4, "Women", Verse 34.
} 
the society. History of Islam exhibited good examples of women who had immeasurable contributions. Nosaybah is an iconic Muslim female who participated in the battle of Badr and has suffered wounds of defending the Prophet s.a.w. Aisha, the mother of believers, was considered scholarly as she had contributed to preserving knowledge from the teachings of Prophet s.a.w to the Muslim world. Many hadiths (prophetic traditions) of Muhammad s.a.w were authentically transmitted by her. Other Muslim women scholars whose scholarly contribution Muslims take pride in were Faatimah Al-Jawzdaaniyah who had the best knowledge of Isnaad (Saleem, 2005) and the best memory of any scholar of her era and 'Ajeebah Al-Baaqdaariyah who was the only one in the world in her time to narrate certain reports (Saleem, 2005). If women empowerment implies participation, Islam also recognizes this. She does not only participate within her household but it extends beyond that. Islam intrinsically promotes women to presume this role.

\section{Markazosshabab and Women Empowerment}

Markazosshabab does not ignore the important contribution of women in the organization and to society in general. It suffices to remark that women are the backbone of the organization as it is more populated by them than their male counterparts. They are given relative independence to run their own affairs. Initially, the women sector was coalesced with the men sector. As the time passed by, women department was established and freedom is enjoyed by them to organize their own activities without interference of the men wing.

Later, this has been transformed into formal institution and was registered in the Philippine security exchange $^{3}$ and named as Majlis ala lilnisa el Muslimat in 1999. In turn, all activities of women had been implemented by women only.

\section{Majlisa'la and Decision Making}

In terms of decision making, women are given the prerogative to design and execute their own activities. They range from various activities, aiming at Muslim women from all walks of life. All activities from different committees are discussed and decided among women executive council. Their counterparts are only expected to intervene in when necessary. This transpires only when their attention is being called upon by women council especially in terms of financial constraints.

...they provide us financial assistance every month. They give us budget for around 10 thousands. In return, they can receive commission from contribution of our women members. It is like reciprocal. One instance is when we purchased our women department's office. We were lacking financially and our brothers extended help to us. But at the same, we are encouraged to stand on our own because we are large in terms of membership. By that, we have more financial capability than them ${ }^{4}$.

Other than that, women decide independently at their discretion to run their affairs which are exclusively designed for women. As for other decision matters, all matters related to Markazosshabab activities and plans that fall under its wide array of mission, vision, and objectives are discussed and presented in Majlis al-Shoura (Consultative Council) General Assembly. In this, women members are represented in the Shoura Council. There are 10 women members who are part of Majlis al-Shoura, while there are 50 male members. The mode of conduct in Majlis al-Shoura is discussion and deciding matters pertaining to its activities and future plans

\footnotetext{
${ }^{3}$ Personal communication, Amai Manabilang, Marawi City, December 1, 2014.

4 Personal communication, Amai Manabilang, Marawit City, December 15, 2014.
} 
from different departments of Markazosshabab. Every department is duly expected to report their activities for one year span with discerning assessment from Majlis al-Shoura members.

Asked about their opinion on their representation in the council, all four interviewees almost had the same remarks. They all concurred that they are given a chance to voice their opinion with time allotted to them and it is taken into consideration by the body. However, the president of the women sector has purported that the time given is not enough and there is a tendency of digression from the topic being presented:

The discussion is for all of us. We, women, can give reaction or opinion. It depends on us if we want to. And we are given a chance to voice our thoughts. It is just that we are given no ample time to raise our opinion. It is always either 5 or 10 minutes. And sometimes what we speak of is not in alignment with the discussed matter. So we stick to the principles of shoura. There's no use of being members if we are not allowed to raise our opinions ${ }^{5}$.

As for their number in Majlis al-Shoura, they are asked about their views of their small numbers compared to the number of male counterparts which amounted to 50 members. There is no dissatisfaction that occurred in the interviews over their representation. It has been found out that there was no female representation in the beginning but it was opened for women in later years ${ }^{6}$. It is just recently that their male counterparts demand for five more members' increase which will be 15 in total. However, one informer who is also one of the executive members of the women sector and also a member of Shoura Council has enunciated that female representation is necessary in the council and that is the reason why they are being represented. In fact, there is a demand of five more women members in the council.

To me, we are not taken for granted because it is their very idea to include us in Majlis al-Shoura. There is a need for women representation. Maybe because they believe that women have a sound thinking like it says in hadith of Prophet s.a.w that a righteous woman is better than thousand men. So that's maybe the reason. It is just that women are small in number. But they have requested already to increase our number ${ }^{7}$.

They are not only asked to raise their opinions but they are in position to vote for candidates to be elected as part of the consultative and executive council. Women sector has their own separate executive council in which selection of members is based on election. These members are presented to council via election for Shoura Council members. Everyone in Majlis al-Shoura members including women has right vested in them to vote in election ${ }^{8}$.

\section{Majlisa'la and Activities}

Majlisa'la members also known as akhawat, sisters in English, are not only engaged in one activity that is to convey Islam to others. $D a^{\prime}$ wah for youths and women is the principal activity of akhawat but there are also other sorts of activities operating under their jurisdiction as a separate department of Markazosshabab. Women sector activities encompass education, politics, economic, and social aspects. It is instilled in the minds of women that their mission revolves around this comprehensiveness of their approach. This is evident in one of the executive members' remarks:

The mission of Markaz is Islam that covers all dimensions. $/ / \mathrm{hmm} / /$ it is like all aspects including spiritual. So whatever we do is defined by being a Muslim. We also educate our mind. //thinking// we have to be wise? We can't be like

\footnotetext{
${ }^{5}$ Personal communication, Amai Manabilang, Marawi City, December 5, 2014.

${ }^{6}$ Personal communication, Amai Manabilang, Marawi City, December 5, 2014.

7 Personal communication, Amai Manabilang, Marawi City, December 8, 2014.

8 Personal communication, Amai Manabilang, Marawi City, December 5, 2014.
} 
having big stomach when small head //laugh// but we can't have it all intelligence while there's no earning for living. It should be balanced... and also our health.

...it also teaches us how to live a good life in this world...religiosity is inculcated and this makes a person careful in his/her dealing...to avoid doing illegal business that may cause chaos in society like riba (interest)...any thing that harms the society ${ }^{9}$.

Aside from that, their activities are systematically organized in such a way that each activity is delegated to corresponding committee. Upon the directives of the president and head of each committee, activities are being implemented. There are six departments that operate under the women sector: (1) administrative and financial department that is in charge of running the administration in a systematic manner and financing activities; (2) call and education department that is responsible for educating youths and women and organizing events such as seminars, talk, assembly, and related programs; (3) economic department that holds responsibility for managing financial matters; (4) political department which is responsible for political issues that Markaz is involved in. They are to participate in discussions and decisions related to political issues in the society; (5) department of information and public relations which takes charge of disseminating information regarding activities of Majlis; and (6) charitable department which is to hold responsibility for charity such as zakat and sadaqah. These departments undertake their works and activities simultaneously and they are expected to report their activities and other associated matters annually at Majlis al-Shoura General Assembly.

In terms of social problems, another important finding that came out from interviews is that one informant has mentioned they are also able to mediate disputes. There are times that she was asked to mediate a family discord. She would initially counsel but at times she mediates when situation demands for it:

There are times that sisters couldn't bear but to share family problems with me. So what I could do is to listen and I would help if there is any way out I could, like mediating the affairs. But firstly, we need to bear patience...but when there is a demand of interference, we will do what we $\mathrm{can}^{10}$.

In economic terms, they are also encouraged to participate in exercises pertaining to business enterprise or entrepreneurship whereby there are members who are able to gravitate to excel in business ventures because of Markazossahab ${ }^{11}$. In addition, they have their own business establishments such as pharmacy and grocery stores from which they can extract money to be given as allowance for their $d a$ ' wah workers who are in need of money $^{12}$. This is to elaborate that most of the Markazosshabab members or workers are volunteers by nature. They join Markaz just to seek the pleasure of Allah to fulfill His command without expecting to have incentives received in return. It is analogically elaborated by another informant that Markaz is not like a ship that you just have to take a ride then sit and wait wherever it takes you. It is like a plant that you have to make some efforts like watering in order to grow it. Being a member of Markaz is to have the intention what to offer to it or what can you contribute to making it a successful and sustainable organization ${ }^{13}$.

\section{Majlisa'la and Life Changes}

Given from its mission which is grounded in Islamic principles, questions must be asked of what makes it different to be members of Markazosshabab or not. It is to be noted that Markazosshabab is dedicated to

\footnotetext{
9 Personal communication, Amai Manabilang, Marawi City, December 8, 2014.

${ }_{10}$ Personal communication, Amai Manabilang, Marawi City, December 8, 2014.

11 Personal communication, Amai Manabilang, Marawi City, December 8, 2014.

12 Personal communication, Amai Manabilang, Marawi City, December 11, 2014.

13 Personal communication, Amani Manabilang, Marawi City, December 13, 2014.
} 
delivering goodness to society as it is believed to be a divine mission. The study conducted by Nima on examining the impact of religious groups of the changing roles of Meranao women including Markaz focusing on its women sector revealed several factors. These are establishments of different religious assemblies organized by the religious groups, donning the hijab, concept on integration of Islamic and Western education, circulation of Islamic literature, and active participants in community activities (Ni'mah, 2014).

It is also of great importance to examine the impact of Markaz mission on its members. This study is interested to find out if there are changes due to joining Markazosshabab among selective members of the women sector. Asked about their views on what makes it different after becoming members of this organization, all have concurred on how it impacts their lives. Two of the informants declared that being members of Markazosshabab taught them how to value time. The former posited that she found her spouse through this group and they have dedicated their lives to serving its purpose, while the latter has given her emphasis on becoming more patient, this is because the dynamism in the group helps them to be patient and race towards goodness and to help others, family, relatives, and whoever needs help. Other informant gave emphasis on impact towards herself especially on her personality. She posited that being attached to Markazosshabab helped her in transforming herself. Could it have been not through Markaz, she will not have the same feeling towards herself.

...It is very huge...on the personality level, knowledge...and Allah made them the reason why I have a little faith and I even keep improving myself... and I do goodness it is because of them ${ }^{14}$.

One informant has expressed her comprehensive view on impact on her by enhancing her concern towards others and connection with the masses. She explained that this was made possible through Markaz. Further, she noted that being a member helped her to invest here in this life to enter paradise.

I mean my connection and my concern to others will not be like this. And when I compare myself to others of my age and also older than me, they don't have connection with the people, concern for the society, concern for educating the people, concern for cleansing oneself like Islamizing the people in a proper way. That is my personal indicator. I am thankful to Allah that I am part of this and I am not like other people who do not have a mission to convey. So I feel, Alhamdulillah, that there is huge impact on my lifestyle and how to live my life in this world and especially in the hereafter for all our efforts are for seeking the pleasure of Allah. How are we going to enter paradise, we work in how are we going gain a good life in the hereafter. Praise be to $\mathrm{Allah}^{15}$.

The informants, who are executive members of the women sectors, have testified of how being involved in Markazosshabab from its inception has delivered apparent changes in their lives. They have compared their life before and after getting involved in the organization and have made confessions on how it impacts their lifestyle and approach to life.

\section{Zakat and Women Sector}

The women sector of Markazossahab has also its separate zakat (almsgiving) wing. Since they have a separate office, the man's wing gave them the freedom and prerogative to collect their zakat at their own disposal. They independently collect the zakat on their own without interference of the male department. Decisions like how much to be collected and distributed are taken by the executive members of women sector.

\footnotetext{
${ }_{15}$ Personal communication, Mani Manbilang, Marawi City, December 20, 2014.

15 Personal communication, Amai Manabilang, Marawi City, December 19, 2014.
} 
In the case of women, they prioritize to give zakat collection to their volunteers and $d a$ 'wah workers because they fall under the categories of eight beneficiaries. They qualify to receive zakat because these are their own workers who do not have income ${ }^{16}$. Other than that, they give and distribute zakat upon deliberation in the council meeting. Then they decide who are qualified to receive based upon their recommendation. The other means they execute is they do survey about who are deserving beneficiaries:

...the other way is that I and my members survey who are needy people. And what we do is to secretly hand to them our monetary help. We also reach out to the victims of accidents, and also travellers who are short of finance, and also for matrimonial matter especially when the groom has to be wed out are necessary circumstances. This inevitability could forge two families into conflict. So, we help to avoid this and facilitate the easy process of wedding by handing financial assistance.

....and also those who are admitted to hospital. And what I do is I go by myself to hospital and extend personally our monetary help ${ }^{17}$.

The women sector has the means of distributing zakat after doing survey by its members. Their way of distributing is diverse where the utmost aim is to cater the needs of needy people they have the knowledge of. However, their focus is on their members who are in need of assistance.

In terms of transparency, Zakat wing is subject to the obligation to present an annual report about the spending of zakat to the council. There is a yearly Majlis al-Shoura General Assembly whereby the whole expenditure of Markazosshabab is presented to the body. Every sector involved is responsible to report their activities and plans including all spending with transparency.

\section{Conclusions}

Islam and development are inseparable. Development is not new to Islam as it is part of its doctrinal belief that Allah commands Muslims to develop society and mankind at large. Islam requires that development starts first within oneself. Society will be developed only when inner development is acquired. It is encompassing in a sense that it includes spiritual, physical, and emotional development. The responsibility to bring about development is understood in the light of vicegerency in Islam. Allah sends mankind to earth to fulfil everyone's responsibilities and duties to bring mercy to mankind. Mercy also includes the concept of development. Women are given opportunities to develop their personalities as contributors to the welfare of society. Women status is never disregarded in the teachings of Islam. As a matter of fact, their status is highly regarded and recognized. This is to be found in Qur'an and prophetic traditions as well as in the history of Islam after the death of the Prophet s.a.w.

The notion that Islam is a faith translated into action is evident in the example of Markasizooshabab al-Muslim fil Filibbin, given its guiding Islamic principles that contribute to development, Markaz was able to make this conspicuous in its programs that promote women empowerment. It has given women freedom to run their own organizational activities. Maj-lisula 'la was established and it has its own executive members that are being operated by women themselves. They are given prerogative to organize programs of different varieties that are exclusive for women. Also, they have zakat and charitable committee separate from Zakat wing of men sector. Markazosshabab is able to inculcate in their women members psyche on the significant role to reform society.

\footnotetext{
16 Personal communication, Amai Manabilang, Marawi City, December 11, 2014.

17 Personal communication, Amai Manabilang, Marawi City, December 11, 2014.
} 


\section{References}

AbulHasan, M. S. (2002). Waqf, perpetual charity and poverty alleviation. International Journal of Social Economics, 29(1.2), 135-151.

Armer, J. M., \& katsillis, J. (2001). Modernization theory. In E. Borgatta and M. L. Borgatta (Eds.), Encyclopedia of sociology 3. New York: Gale Group.

Asim, \& Bukhari. (2013). Women empowerment in a Muslim society: A practical observation. Intertidisciplenary Journal of Contemporary Research Business, 5(1), 768-778.

Berger, J. (2003). Religious non-governmental organizations: An exploratory analysis. International Journal of Voluntary and Non-Profit Organizations, 14(1), 15-39.

Bowen, K. (2013). Religion, participation, and charitable giving. Canadian Centre for Philantropy. Retrieved from http://www. imaginecanada.ca/files/www/en/giving/n-vc1sen.pdf

Chaves, M., Stephens, L., \& Galaskiewicz, J. (2014). Does government funding suppress nonprofits' political activity? American Sociological Review, 69(2), 292-316.

Floyd, R. (2005). Empowerment. New York: Universe.

Foa, R. (2014). Indices of social development. Retrieved from http://www.indsocdev.org/resources/Indices\%20of\%20Social\%20 Development\%20Handbook.pdf

Lee Mardsen, B. (2008). Obama and a faith-based US foreign policy. International Affairs, 88(5), 964.

Malhotra, A., \& Schuler, S. R. (2004). Measuring women's empowerment as a variable in international development. Background Paper Prepared for the World Bank Workshop on Poverty and Gender: New Perspectives.

Maszlee, M. (2012). Religion, civil society, and good governance: The "pertubuan jamaah Islah Malaysia": (JIM) experience. International Journal of Islamic Thought, 8, 5-19.

McCarthy, S. K. (2013). Serving society, repurposing the state: Religious charity and resistance in China. The China Journal, 70, 48-72.

Moyer, J. M. A., Sinclair, J., \& Spaling, H. (2012). Working for God and sustainability: The activities of faith-based organizations in Kenya. Voluntas, 23, 959-992.

Ni'mah, B. (2014). The impact of three religious groups on the changing roles of meranao women: A study of tablīgh jama'ah, markazosshabab fil-filibbin and ahl al-bayt. Master thesis, International Islamic University Malaysia.

Noy, D. (2009). Types material and spiritual conceptions of development: A framework of ideal. Journal of Developing Societies, $25,275-307$.

Olivier, R. (2005). The predicament of "civil society" in Central Asia and Greater Middle East. International Affair, 81(5), 1001-1012.

Pew Forum. (2010). Religion and international development. Pew research center's religion and public life project. Retrieved from http://www.pewforum.org/2006/03/06/religion-and-international-development/

Rakodi, C. (2013). A guide to analyzing the relationships between religion and development. Religion and Development Programme. Retrieved from http://www.religionsanddevelopment.org/files/resourcesmodule/@random454f80f60b3f4/1315 399993_working_paper_67__complete_for_web.pdf

Ramadan, T. (2010). Social justice: An Islamic perspective. Islamic Circle of North America. Retrieved from http://icnacsj.org/ wp-content/uploads/2015/02/Social-Justice-Booklet.pdf

Saleem, A. A.-M. (2005). Important lessons for Muslim women. Riyadh: Darussalam.

Schmidt, V. H. (2010). Modernity and diversity: Reflections on the controversy between modernization theory and multiple modernist. Social Science Information, 49(4), 511-538.

Sen, A. (1995). Inequality reexamined. Oxford: Clarendon Press.

Serrano, I. R. (2015). Civil society in the Philippines: Struggling for sustainability. Retrieved from http://www.prrm.org/wpcontent/uploads/2009/11/civil.pdf

Shah, A. (2013). Non-governmental organizations on development issues. Global Issues. Retrieved from http://www.globalissues. Org

Vanderwoerd, J. R. (2008). Religious characteristics of government-funded faith-related social service. Organizations Social Work and Christianity, 35(3), 258-286. 